\title{
Lobomikosis pada lumba lumba hidung botol Tursiop aduncus
}

\author{
Agustin Indrawati ${ }^{1, *}$, Lee Xia Meen ${ }^{2}$ \\ ${ }^{1}$ Divisi Mikrobiologi Medik, Departemen Ilmu Penyakit Hewan dan Kesmavet, Fakultas Kedokteran Hewan, Institut \\ Pertanian Bogor, Bogor \\ ${ }^{2}$ Program Pendidikan Profesi Dokter Hewan, Fakultas Kedokteran Hewan, Institut Pertanian Bogor, Bogor
}

\begin{abstract}
ABSTRAK: Lobomikosis merupakan penyakit yang menyerang bagian kulit yang disebabkan oleh Lacazia loboi (yeast-like organism) dari ordo Onygenales. Tulisan ini melaporkan seekor lumba-lumba hidung botol Indo Pasifik Tursiop aduncus jantan berumur 14 tahun yang mengalami kelainan pada kulit berupa nodul-nodul ulseratif menyerupai ringworm pada sirip ekor. Gejala yang ditimbulkan dengan cepat menyebar dan gejala pada permukaan kulit mengalami penggabungan nodul yang menyerupai bunga dan disertai adanya perdarahan. Pemeriksaan laboratorium ditemukan bentukan sel khamir dan bentuk unisel. Pengobatan dilakukan dengan menggunakan antifungal ketoconazole $200 \mathrm{mg}$ (mycoral ${ }^{\circledR}$ ) dan ketoconazole cream $2 \%$ selama 30 hari. Pengobatan lain yang digunakan adalah antihistamin Homochlorcyclizine HCl $20 \mathrm{mg}$ (Homoclomin ${ }^{\circledR}$ ) dan antibiotika Quinolone $500 \mathrm{mg}$ (Ciproxin ${ }^{\circledR}$ ) untuk mengobati infeksi sekunder akibat bakteri. Lumba-lumba hidung botol Indo Pasifik dinyatakan sembuh dengan menghilangnya nodul ulseratif dari sirip ekor setelah 30 hari pengobatan.
\end{abstract}

\section{Kata kunci:}

khamir, ketoconazole, lobomikosis, Tursiop aduncus

\section{PENDAHULUAN}

Lumba lumba hidung botol indo pasifik Tursiop aduncus merupakan salah satu golongan mamalia laut yang banyak ditemukan diperairan Indonesia dan banyak ditemukan di pusat- pusat konservasi. Penyakit kulit yang disebabkan oleh agen berupa bakteri, virus, jamur ataupun ektoparasit sering ditemukan pada mamalia air. Lobomikosis merupakan penyakit jamur yang disebabkan oleh jamur Lacazia loboi (ordo Onygenales). Penyakit lobomikosis dapat menginfeksi manusia dan hewan khususnya dari hewan ordo Cetacea (Rotstein et al. 2009).

Lacazia loboi merupakan organisme menyerupai khamir yang bersifat unisel dan berkembang biak dengan cara budding. Gambaran klinis penyakit ditandai adanya pembentukan lesi putih dan abu-abu, nodul merah atau verukosa (mirip kembang kol), kadang diikuti granuloma serta adanya ulserasi dan membentuk nodul papiler (Francesconi et al. 2014). Lesi menjadi mudah berdarah jika terjadi trauma kecil. Daerah yang paling sering terkena adalah bagian anterior dorsum, sirip punggung, sirip dada, rostrum, permukaan kranial dorsal, dan tubuh bagian tengah (Vilela \& Mendoza 2018). Tulisan ini melaporkan kasus lobomikosis pada lumba-lumba hidung botol Indo Pasifik Tursiop aduncus yang belum dilaporkan di Indonesia sehingga dapat menjadi acuan dalam melakukan tindakan medis pada mamalia laut.

\section{- KASUS}

Sinyalemen: Seekor lumba-lumba Indo Pasifik Tursiop aduncus yang dipelihara di PT Wersut Seguni Indonesia, umur 14 tahun dan berjenis kelamin jantan, bobot badan 97 $\mathrm{kg}$ menderita lesi pada bagian sirip dengan bentuk menyerupai ringworm. Pemeriksaan klinis: Hasil pemeriksaan sirip menunjukkan adanya gangguan pada daerah sirip ekor. Temuan klinis: Gangguan pada sirip ekor diawali dengan adanya bentukan seperti ringworm dengan batas tepi yang jelas (Gambar 1A) dan semakin lama semakin besar menumpuk seperti bunga (Gambar 1B). Bagian ujung sirip ekor mengalami ulserasi dan perdarahan. Gejala yang sama juga ditemukan di daerah sekitar mata (Gambar 1C).



Gambar 1. Lobomikosis pada sirip ekor lumba-lumba. (A) kondisi awal tampak seperti ringworm dengan batas tepi yang jelas, (B) perlukaan pada ujung sirip, (C) lesio di sekitar kelopak mata, dan (D) sirip ekor yang mulai sembuh setelah pengobatan 30 hari.

Diagnosa penunjang: Pemeriksaan cepat menggunakan $\mathrm{KOH} \mathrm{10 \%} \mathrm{dan} \mathrm{pewarnaan} \mathrm{sederhana} \mathrm{diperoleh} \mathrm{morfologi} \mathrm{sel}$

Diterima: 04-05-2020 | Direvisi: 15-06-2020 | Disetujui: 18-06-2020

(C) 2020 CC-BY-SA. Ini adalah artikel Open Access yang didistribusikan berdasarkan ketentuan dari Creative Commons Attribution ShareAlike 4.0 International License (https://creativecommons.org/licenses/by-sa/4.0/). 
khamir bentuk unisel dan bentukan budding. Diagnosa: Lobomikosis. Diferensial diagnosa: Sporotrichosis, Blastomikosis dan paracoccidiodomikosis. Prognosa: Fausta. Terapi: Lumba-lumba diberikan pengobatan 30 hari menggunakan antifungal Ketoconazole cream $2 \%$ dan ketoconazole tablet $200 \mathrm{mg}$ (mycoral $\AA$ ), anti-histamine 20 $\mathrm{mg}$ (homoclomin ${ }^{\circledR}$ ), dan antibiotika quinolone $500 \mathrm{mg}$ (ciproxin ${ }^{\circledR}$ ) selama 5 hari.

\section{- HASIL DAN PEMBAHASAN}

Gambar 1 menunjukkan kondisi klinis pada lumba-lumba yang ditandai oleh pembentukan lesi putih dan abu-abu seperti ringworm pada sirip ekor dan menyebar. Lesi yang menyebar dan berbentuk menyerupai bunga serta ada ulserasi dan perdarahan baik pada sirip ataupun mata bagian atas (Gambar 1A-C). Berdasar pemeriksaan klinis diduga lumbalumba menderita lobomikosis yang disebabkan oleh jamur Lacazia loboi. Infeksi agen ini bersifat subkutan dan membentuk granuloma. Lumba-lumba Tursiop truncatus yang menderita lobomikosis menunjukkan adanya noduli di beberapa tempat dan kadang berwarna merah bersifat verukosa. Lesi yang muncul lama kelamaan dapat membentuk nodul papiler yang melebar dan semakin lama menjadi berbentuk plak berukuran Lesi yang muncul menjadi mudah berdarah (Vilela \& Mendosa 2018)

Ketoconazole merupakan anti fungal berspektrum luas dan dapat digunakan untuk pengobatan pada kasus lobomikosis. Ueda (2013) melaporkan efektifitas ketoconazole untuk pengobatan lumba-lumba yang menderita lobomikosis di Jepang. Gejala lobomikosis pada lumba-lumba diawali dengan pruritis, granuloma kronis dan ulseratif dan memiliki kemiripan pada lumba-lumba Indo Pasifik Tursiop aduncus. Tursiop aduncus yang dipelihara di PT Wersut Seguni Indonesia yang diduga menderita lobomikosis berhasil diobati dengan baik. Hasil pengobatan menunjukkan keberhasilan dimana lesio yang terjadi mengalami kesembuhan dengan tanpa meninggalkan adanya kecacatan pada sirip ekor (Gambar1D).

\section{- SIMPULAN}

Lacazia loboi yang diduga sebagai penyebab penyakit jamur lobomikosis dapat disembuhkan dengan pemberian Ketoconazole $200 \mathrm{mg}$ dan ketoconazole salep selama 30 hari dengan kombinasi anti histamine dan antibiotika untuk mencegah infeksi sekunder yang disebabkan oleh bakteri.

\section{- UCAPAN TERIMA KASIH}

Terima kasih kepada Drh Dwi Restu Seta, MM dan Drh Elmavian dari PT Wersut Seguni Indonesia, salah satu Pusat Konservasi Mamalia Air Indonesia, yang telah memfasilitasi pengambilan data dalam studi kasus ini.

\section{- INFORMASI PENULIS}

Penulis untuk Korespondensi

*AE: titin.seta@gmail.com

Divisi Mikrobiologi Medik, Departemen Ilmu Penyakit Hewan dan Kesmavet, Fakultas Kedokteran. Institut Pertanian Bogor.

Jl. Agatis Kampus IPB Dramaga Bogor 16680

\section{n PUSTAKA ACUAN}

Francesconi VA, Klein AP, Santos APBG, Ramasawmy R, Francesconi F. 2014. Lobomycosis: epidemiology, clinical presentation, and management options. Therapeutics and Clinical Risk Management. 10(1):851.

Rotstein DS, Burdett LG, McLellan W, Schwacke L, Rowles T, Terio KA, Schultz S, Pabst A. 2009. Lobomycosis in offshore bottlenose dolphins (Tursiops truncatus), North Carolina. Emerging Infectious Diseases. 15(4):588-590.

Ueda K, Sano A, Yamate J, Itano Nakagawa E, Kuwamura M, Izawa T, Tanaka M, Hasegawa Y, Chibana H, Izumisawa Y, Miyahara H. 2013. Two cases of lacaziosis in bottlenose dolphins (Tursiops truncatus) in Japan. Case Reports in Veterinary Medicine. 1(1):1-9.

Vilela R, Mendoza L. 2018. Paracoccidioidomycosis ceti (Lacaziosis/Lobomycosis) in Dolphins. Emerging and Epizootic Fungal Infections in Animals. 1(1):177-196. 